Prepared in cooperation with the U.S. Environmental Protection Agency

Coeur d'Alene Basin Environmental Monitoring Program, Surface Water, Northern Idaho-Annual Data Summary, Water Year 2017

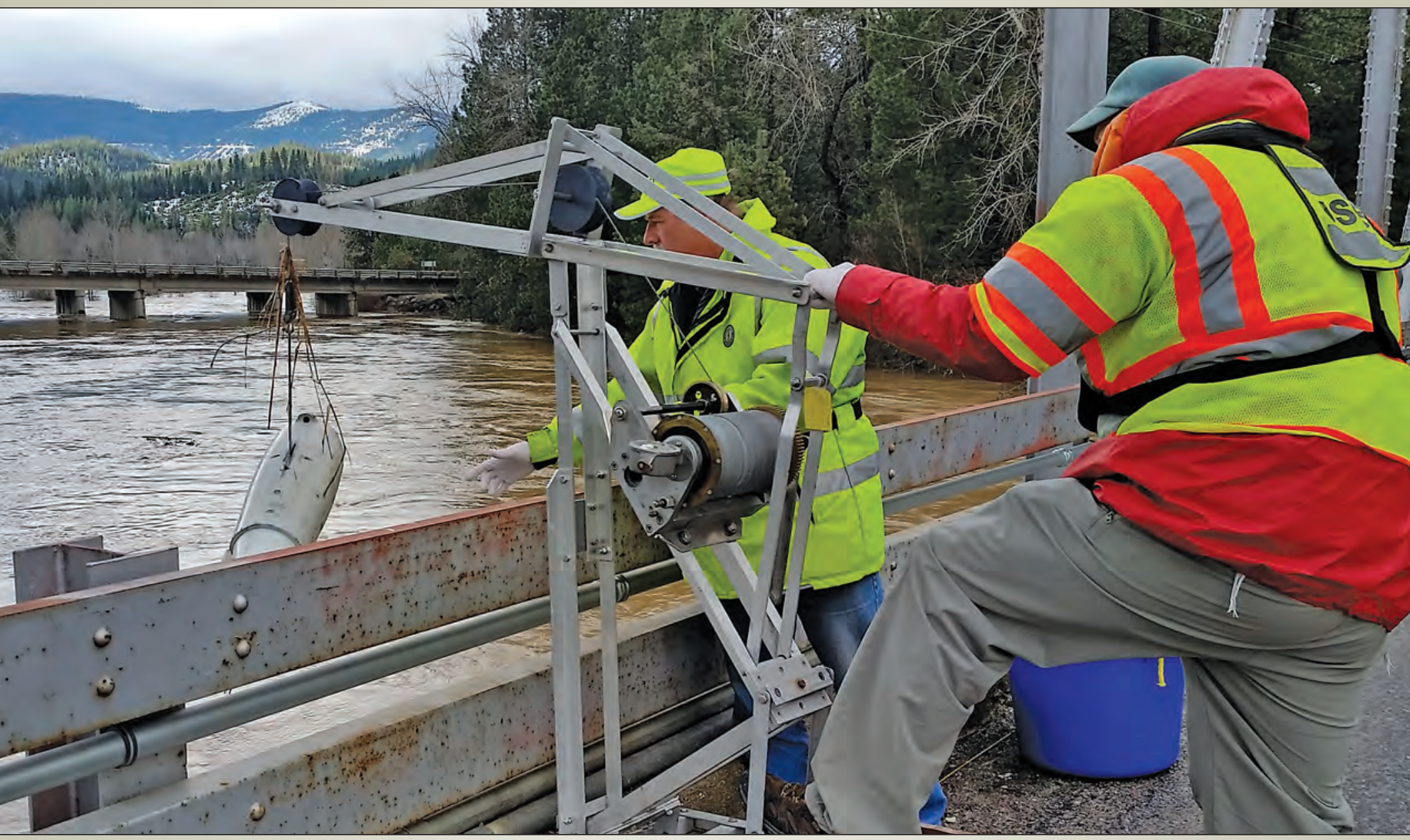

Open-File Report 2018-1113 
Cover: U.S. Geological Survey hydrologic technicians sample the Coeur d'Alene River near Cataldo, USGS site 12413500, during flooding in March 2017. Photograph by Daniel Hess, U.S. Geological Survey, March 17, 2017. 


\section{Coeur d'Alene Basin Environmental Monitoring Program, Surface Water, Northern Idaho- Annual Data Summary, Water Year 2017}

By Lauren M. Zinsser

Prepared in cooperation with the U.S. Environmental Protection Agency

Open-File Report 2018-1113

U.S. Department of the Interior

U.S. Geological Survey 


\section{U.S. Department of the Interior \\ RYAN K. ZINKE, Secretary}

\section{U.S. Geological Survey James F. Reilly II, Director}

U.S. Geological Survey, Reston, Virginia: 2018

For more information on the USGS-the Federal source for science about the Earth, its natural and living resources, natural hazards, and the environment-visit https://www.usgs.gov/ or call 1-888-ASK-USGS (1-888-275-8747).

For an overview of USGS information products, including maps, imagery, and publications, visit https://store.usgs.gov/.

Any use of trade, firm, or product names is for descriptive purposes only and does not imply endorsement by the U.S. Government.

Although this information product, for the most part, is in the public domain, it also may contain copyrighted materials as noted in the text. Permission to reproduce copyrighted items must be secured from the copyright owner.

Suggested citation:

Zinsser, L.M., 2018, Coeur d'Alene Basin Environmental Monitoring Program, surface water, northern Idaho-Annual data summary, water year 2017: U.S. Geological Survey Open-File Report 2018-1113, 15 p., https://doi.org/10.3133/ofr20181113.

ISSN 2331-1258 (online) 


\section{Contents}

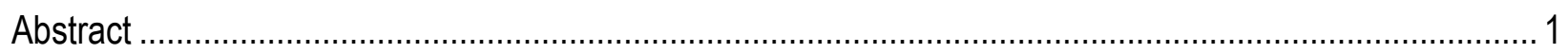

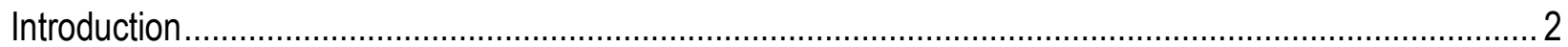

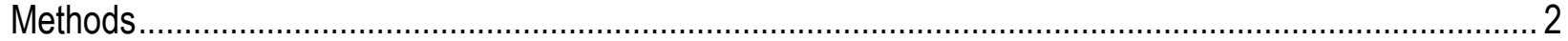

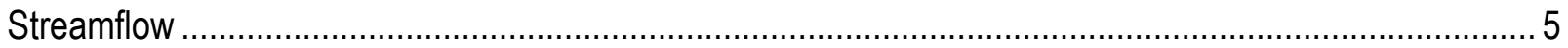

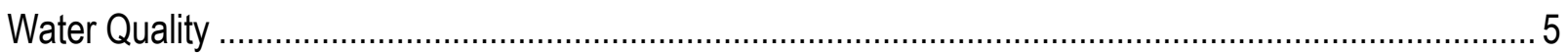

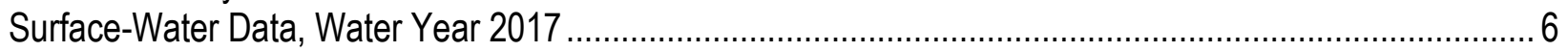

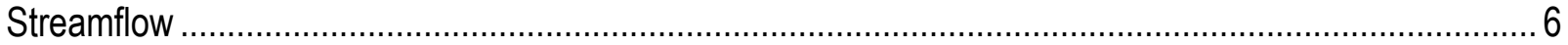

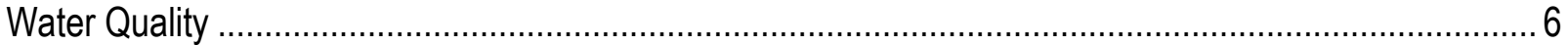

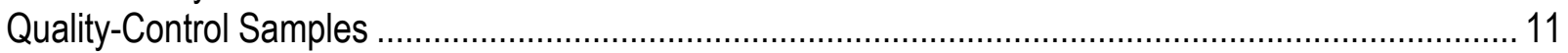

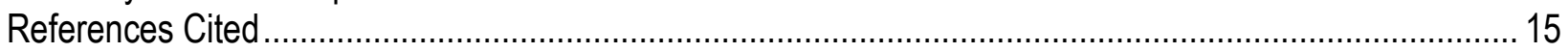

\section{Figures}

Figure 1. Maps showing location of Basin Environmental Monitoring Program (BEMP) surface-water monitoring sites in the Coeur d'Alene River and Spokane River drainage basins, northern Idaho

Figure 2. Graphs showing streamflow at Basin Environmental Monitoring Program (BEMP) sites with continuous streamgages in the Coeur d'Alene River and Spokane River drainage basins, northern Idaho, water year 2017

Figure 3. Graphs showing constituent concentration versus streamflow in the Coeur d'Alene River near Cataldo (site 12413500), northern Idaho

Figure 4. Graphs showing constituent concentration versus streamflow in the Coeur d'Alene River at Rose Lake (site 12413810), northern Idaho

Figure 5. Graphs showing constituent concentration versus streamflow in the Coeur d'Alene River near Harrison (site 12413860), northern Idaho.

Figure 6. Boxplots showing total lead concentrations at Basin Environmental Monitoring

Program (BEMP) sites in water year 2017 versus 2007-16.

Figure 7. Boxplots showing dissolved zinc concentrations at Basin Environmental Monitoring

Program (BEMP) sites in water year 2017 versus 2007-16 .

Figure 8. Boxplots showing dissolved cadmium concentrations at Basin Environmental Monitoring Program (BEMP) sites in water year 2017 versus 2007-16

\section{Table}

Table 1. Basin Environmental Monitoring Program (BEMP) surface-water monitoring sites in the Coeur d'Alene River and Spokane River drainage basins, northern Idaho. 


\section{Conversion Factors}

U.S. customary units to International System of Units

\begin{tabular}{|c|c|c|}
\hline Multiply & By & To obtain \\
\hline \multicolumn{3}{|c|}{ Length } \\
\hline foot $(\mathrm{ft})$ & 0.3048 & meter $(\mathrm{m})$ \\
\hline \multicolumn{3}{|c|}{ Flow rate } \\
\hline cubic foot per second $\left(\mathrm{ft}^{3} / \mathrm{s}\right)$ & 0.02832 & cubic meter per second $\left(\mathrm{m}^{3} / \mathrm{s}\right)$ \\
\hline \multicolumn{3}{|c|}{ International System of Units to U.S. customary units } \\
\hline Multiply & By & To obtain \\
\hline \multicolumn{3}{|c|}{ Volume } \\
\hline liter $(\mathrm{L})$ & 1.057 & quart (qt) \\
\hline liter (L) & 0.2642 & gallon (gal) \\
\hline \multicolumn{3}{|c|}{ Mass } \\
\hline gram $(\mathrm{g})$ & 0.03527 & ounce, avoirdupois (oz) \\
\hline
\end{tabular}

\section{Datums}

Vertical coordinate information is referenced to the North American Vertical Datum of 1988 (NAVD 88).

Horizontal coordinate information is referenced to the, North American Datum of 1983 (NAD 83).

Altitude, as used in this report, refers to distance above the vertical datum.

\section{Supplemental Information}

Concentrations of chemical constituents in water are given in either milligrams per liter $(\mathrm{mg} / \mathrm{L})$ or micrograms per liter $(\mu \mathrm{g} / \mathrm{L})$.

\section{Abbreviations}

BEMP Basin Environmental Monitoring Program

EPA U.S. Environmental Protection Agency

RPD relative percent difference

USGS U.S. Geological Survey 


\title{
Coeur d'Alene Basin Environmental Monitoring Program, Surface Water, Northern Idaho-Annual Data Summary, Water Year 2017
}

By Lauren M. Zinsser

\begin{abstract}
Streams within the Coeur d'Alene River drainage basin in northern Idaho have been extensively affected by historical mining activities and are subject to ongoing remedial actions as part of the Bunker Hill Mining \& Metallurgical Complex Superfund Site. The U.S. Geological Survey (USGS) operates 12 real-time streamgages and collects surface-water-quality samples two to four times annually at 20 sites in the Spokane River and Coeur d'Alene River drainage basins. These data are used by the U.S. Environmental Protection Agency (USEPA) to monitor cleanup progress and to support decisions related to implementing remedial actions throughout the basin. USGS data collection highlights from water year 2017 include:

- A rain-on-snow event in March 2017 produced high streamflows and flooding in the basin.

- The March event mobilized high concentrations of total metals (cadmium, lead, zinc, and others) in the Coeur d'Alene River near Cataldo, at Rose Lake, and near Harrison; these concentrations were among the highest that have been measured at these sites during flood events sampled by the USGS.

- Total lead and dissolved zinc and cadmium concentrations decreased in Canyon Creek in 2017 when compared with water years 2007-16; in contrast, concentrations of dissolved zinc and cadmium increased in Ninemile Creek when compared with water years 2007-16.
\end{abstract}




\section{Introduction}

Streams within the Coeur d'Alene River drainage basin have been extensively altered and impacted by historical mining practices that spread contaminants - including cadmium, lead, and zinc - through soil, sediment, groundwater, and surface water. The impacted area is designated as the Bunker Hill Mining \& Metallurgical Complex Superfund Site and is subject to ongoing remedial actions led by the U.S. Environmental Protection Agency (USEPA).

The Coeur d'Alene River extends across northern Idaho from the Montana border on the east to where it flows into the Spokane River near the Washington border on the west. The Coeur d'Alene River drainage basin is mountainous, with altitudes ranging from 2,000 to 6,850 ft. About 70 percent of the annual precipitation falls as snow during winter (October-April), and streamflows and metal loads normally are highest during spring runoff. However, warm winter Pacific storms can affect the area, bringing heavy rains and warm temperatures that can cause rapid snowmelt and produce high streamflow rain-on-snow events. These events can be associated with high transport of sediment and sediment-bound trace metals. In contrast, streamflows are lowest and dissolved metal concentrations typically are highest during September and October (Clark and Mebane, 2014).

In cooperation with the USEPA, the U.S. Geological Survey (USGS) operates and maintains 12 real-time streamgages and collects surface-water-quality samples two to four times annually at 20 monitoring sites (fig. 1) in the Spokane River and Coeur d'Alene River drainage basins (Clark and Perreault, 2017). This work is part of the Coeur d'Alene Basin Environmental Monitoring Program (BEMP; U.S. Environmental Protection Agency, 2002, 2012), and these data are used to monitor cleanup progress and to inform remedial action implementation decisions. The surface-water BEMP was initiated in 2004; this report highlights data collection results from water year 2017 (October 1, 2016-September 30, 2017).

\section{Methods}

The current surface-water BEMP comprises 20 monitoring sites (fig. 1; table 1). Of these, 12 sites have continuous streamflow-gaging; 14 sites are sampled four times annually; and 6 sites are sampled twice annually (table 1). Each of the 20 sites are sampled during peak snowmelt runoff and fall baseflow; 14 of these sites are also sampled during a winter storm event and the peak hydrograph recession. Additionally, three sites (Coeur d'Alene River near Cataldo, at Rose Lake, and near Harrison) were sampled an extra time during water year 2017 to capture high streamflow conditions in March. 


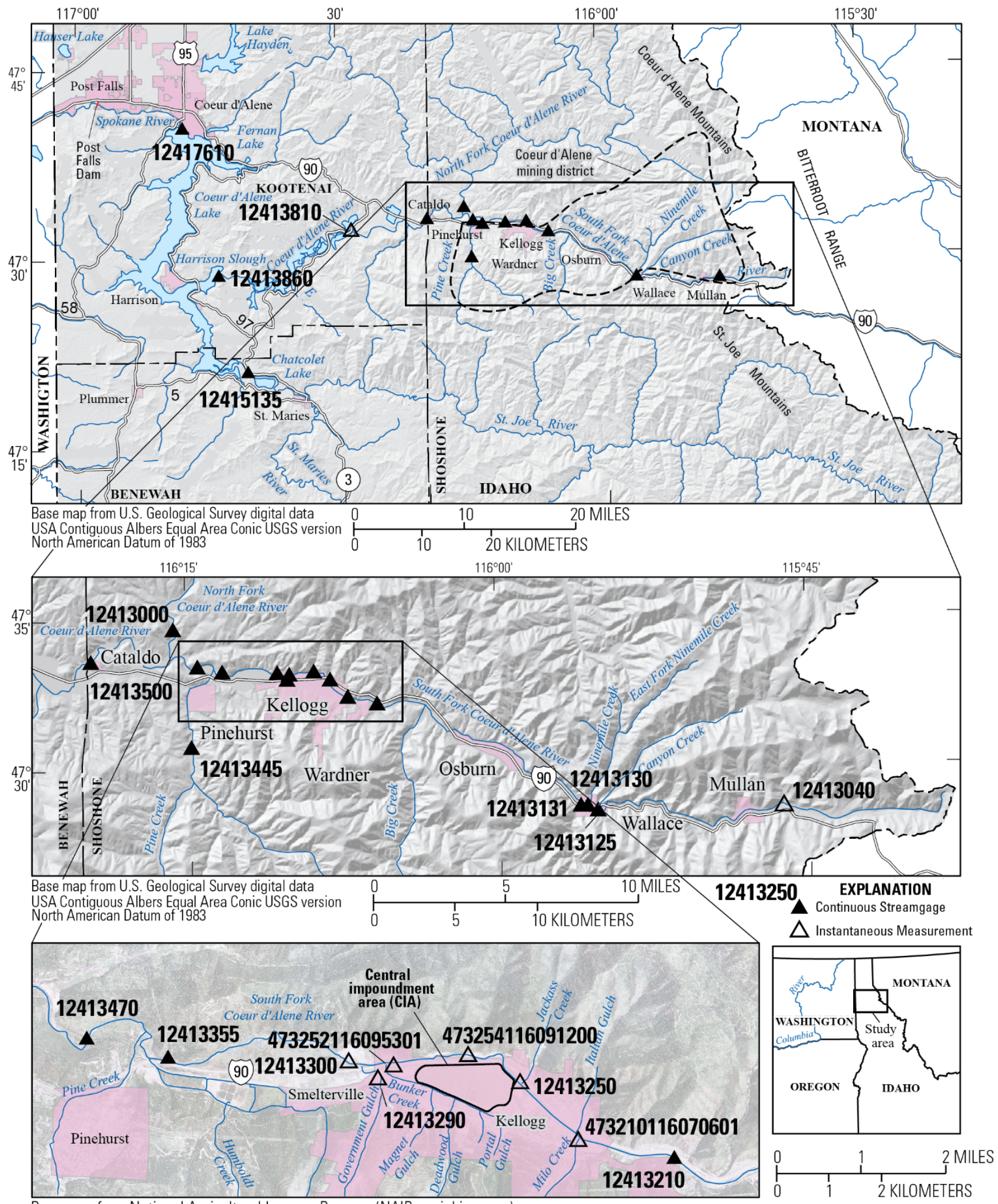

Base map from National Agricultural Imagery Program (NAIP; aerial imagery);

National Hydrology Dataset Plus (NHDPlus; hydrography)

Figure 1. Maps showing location of Basin Environmental Monitoring Program (BEMP) surface-water monitoring sites in the Coeur d'Alene River and Spokane River drainage basins, northern Idaho. 
Table 1. Basin Environmental Monitoring Program (BEMP) surface-water monitoring sites in the Coeur d'Alene River and Spokane River drainage basins, northern Idaho.

[Streamflow and water-quality data collected during water year 2017 can be accessed at https://waterdata.usgs.gov/id/nwis/current/?type=BEMP (U.S. Geological Survey, 2018). Type of streamflow measurement: Continuous ADVM, continuous streamgage with acoustic Doppler velocity meter; continuous stage, continuous streamgage with pressure transducer; instantaneous, streamflow measured at time of sample collection. USGS, U.S. Geological Survey]

\begin{tabular}{|c|c|c|c|c|c|}
\hline USGS site name & $\begin{array}{l}\text { USGS streamgage } \\
\text { or site No. }\end{array}$ & $\begin{array}{l}\text { BEMP site } \\
\text { No. }\end{array}$ & $\begin{array}{l}\text { Sample } \\
\text { schedule } \\
\text { (times } \\
\text { annually) }\end{array}$ & $\begin{array}{c}\text { Type of } \\
\text { streamflow } \\
\text { measurement }\end{array}$ & $\begin{array}{l}\text { Period of } \\
\text { streamflow } \\
\text { record }\end{array}$ \\
\hline $\begin{array}{l}\text { North Fork Coeur d'Alene River at } \\
\text { Enaville }\end{array}$ & 12413000 & NF-50 & 4 & Continuous, stage & $1911-2017$ \\
\hline $\begin{array}{l}\text { South Fork Coeur d'Alene River } \\
\text { above Deadman Gulch, near } \\
\text { Mullan }\end{array}$ & 12413040 & SF-208 & 2 & Instantaneous & 1998-2017 \\
\hline $\begin{array}{l}\text { Canyon Creek above mouth, at } \\
\text { Wallace }\end{array}$ & 12413125 & CC-288 & 4 & Continuous, stage & 1998-2017 \\
\hline $\begin{array}{l}\text { Ninemile Creek above mouth, at } \\
\text { Wallace }\end{array}$ & 12413130 & NM-305 & 4 & Continuous, stage & 1998-2017 \\
\hline $\begin{array}{l}\text { South Fork Coeur d'Alene River } \\
\text { above Placer Creek, at Wallace }\end{array}$ & 12413131 & SF-233 & 4 & Continuous, stage & 2009-2017 \\
\hline $\begin{array}{l}\text { South Fork Coeur d'Alene River at } \\
\text { Elizabeth Park, near Kellogg }\end{array}$ & 12413210 & SF-268 & 4 & Continuous, stage & 1987-2017 \\
\hline $\begin{array}{l}\text { South Fork Coeur d'Alene River at } \\
\text { Kellogg }\end{array}$ & 12413250 & SF-269 & 4 & Instantaneous & $1972-2018$ \\
\hline $\begin{array}{l}\text { Government Gulch Creek near } \\
\text { mouth, at Smelterville }\end{array}$ & 12413290 & BH-GG-0001 & 2 & Instantaneous & 1998-2018 \\
\hline $\begin{array}{l}\text { South Fork Coeur d'Alene River at } \\
\text { Smelterville }\end{array}$ & 12413300 & SF-270 & 4 & Instantaneous & 1966-2017 \\
\hline $\begin{array}{l}\text { South Fork Coeur d'Alene River } \\
\text { above Pine Creek, near Pinehurst }\end{array}$ & 12413355 & SF-270A & 4 & Continuous, stage & 2008-2017 \\
\hline $\begin{array}{l}\text { Pine Creek below Amy Gulch near } \\
\text { Pinehurst }\end{array}$ & 12413445 & PC-339 & 2 & Continuous, stage & $1999-2018^{1}$ \\
\hline $\begin{array}{l}\text { South Fork Coeur d'Alene River } \\
\text { near Pinehurst }\end{array}$ & 12413470 & SF-271 & 4 & Continuous, stage & $1987-2017$ \\
\hline Coeur d'Alene River near Cataldo & 12413500 & LC-50 & 4 & Continuous, stage & $1911-2017$ \\
\hline Coeur d'Alene River at Rose Lake & 12413810 & LC-55 & 4 & Instantaneous & $1971-2017$ \\
\hline Coeur d'Alene River near Harrison & 12413860 & LC-60 & 4 & $\begin{array}{l}\text { Continuous, } \\
\text { ADVM }\end{array}$ & 2004-2018 \\
\hline $\begin{array}{l}\text { St. Joe River at Ramsdell Station, } \\
\text { near St. Maries }\end{array}$ & 12415135 & SJ-65 & 4 & $\begin{array}{l}\text { Continuous, } \\
\text { ADVM }\end{array}$ & 2009-2018 \\
\hline $\begin{array}{l}\text { Spokane River at Lake Outlet, at } \\
\text { Coeur d'Alene }{ }^{2}\end{array}$ & 12417610 & SR-5 & 4 & $\begin{array}{l}\text { Continuous, } \\
\text { ADVM }\end{array}$ & $2014-2018^{2}$ \\
\hline $\begin{array}{l}\text { Milo Creek Outfall at South Fork } \\
\text { Coeur d'Alene River, at Kellogg }\end{array}$ & 473210116070601 & BH-MC-0002 & 2 & Instantaneous & 2013-2018 \\
\hline $\begin{array}{l}\text { Bunker Creek at mouth of culvert, } \\
\text { at Kellogg }\end{array}$ & 473252116095301 & BH-BC-0006 & 2 & Instantaneous & 2013-2018 \\
\hline $\begin{array}{l}\text { Seeps north of Deadwood Gulch } \\
\text { Tailings at Kellogg }\end{array}$ & 473254116091200 & BH-CS-0001 & 2 & Instantaneous & none available \\
\hline
\end{tabular}




\section{Streamflow}

Streamflow at each monitoring site (fig. 1; table 1) was measured using standard USGS procedures as described in Turnipseed and Sauer (2010) and Mueller and others (2013). At nine sites with the real-time streamgages, continuous streamflow records were computed using stage-discharge relationships based on continuous stage measurements that are calibrated to periodic streamflow measurements (Rantz, 1982). At the three sites with streamgages affected by changes in the level of Coeur d'Alene Lake (sites 12413860, 12415125, and 12417610), continuous streamflow records were computed using an index velocity method based on acoustic Doppler velocity meter measurements (Levesque and Oberg, 2012). At the eight sites without continuous streamflow-gaging, streamflow was measured when water-quality samples were collected whenever possible. However, streamflow measurements were occasionally omitted during high streamflow events when maximizing the number of samples collected during short-lived hydrologic conditions was paramount. For these events, streamflow values were calculated using a regression between measured instantaneous streamflow at the site and streamflow measured at a comparable nearby continuous streamgage. As used in this report, daily mean streamflow for water year 2017, and the period of record mean for the daily mean streamflow, were calculated by U.S. Geological Survey (2018).

\section{Water Quality}

Water-quality samples were collected according to the procedures described in U.S. Geological Survey (variously dated) and the Quality Assurance Project Plan specific to the BEMP surface-water program (Clark and Perreault, 2017). Samples were collected using width and depth-integrated techniques and composited with a churn. Water samples for "dissolved" constituent analyses were filtered using a capsule filter with 0.45 -micrometer pores; these constituents are referred to as "dissolved" herein. Nutrient samples were preserved with sulfuric acid and chilled; metals samples were preserved with nitric acid. All analyses except for sediment were conducted at the USGS National Water Quality Laboratory (Denver, Colorado). Sediment analyses (total suspended sediment and percent sand and fines) were conducted at the USGS Cascades Volcano Observatory Sediment Laboratory (Vancouver, Washington).

Quality control samples were collected in accordance with standard USGS procedures (Mueller and others, 2015) and the Quality Assurance Project Plan specific to the BEMP surface-water program (Clark and Perreault, 2017). Two field blanks were collected during each sampling event. For the field blanks, certified inorganic blank water was processed through cleaned equipment in the field according to the normal sample collection and processing procedures (Mueller and others, 2015) and submitted for analysis. One or two split replicates samples were also collected during each sampling event. 


\section{Surface-Water Data, Water Year 2017}

Streamflow and water-quality data collected during water year 2017 can be accessed in its entirety online at https://waterdata.usgs.gov/id/nwis/current/?type=BEMP (U.S. Geological Survey, 2018). Selected results are presented here.

\section{Streamflow}

Water year 2017 was characterized by several high streamflow events. Heavy rainfall in October 2016 led to high streamflows during the period in which baseflows are normally observed. Figure 2 shows mean daily mean streamflow for the streamflow period of record and water year 2017 daily mean streamflow at sites with continuous streamgages in the drainage basins. Rain-on-snow events in February and March 2017 also caused high streamflows, and streamflow during the March event exceeded flood stage $\left(27,600\right.$ cubic feet per second $\left.\left[\mathrm{ft}^{3} / \mathrm{s}\right]\right)$, in the Coeur d'Alene River near Cataldo (site 12413500). In water year 2017, the maximum daily streamflow recorded at this site was $31,200 \mathrm{ft}^{3} / \mathrm{s}$ on March 16; the maximum 15-minute streamflow recorded at this site was 33,700 $\mathrm{ft}^{3} / \mathrm{s}$ on March 17. Following the March event, spring snowmelt runoff throughout the drainage basins occurred at the same time as mean runoff but was somewhat higher than mean runoff at most sites (fig. 2). The main exception was the Spokane River near the lake outlet (site 12417650), which experienced much higher and later runoff flows than mean runoff; these streamflows were likely affected by downstream dam release operations. Summer baseflows throughout the drainage basins were similar in magnitude and timing to mean baseflows (fig. 2).

\section{Water Quality}

The analytical results from water-quality samples collected in the Coeur d'Alene River near Cataldo, at Rose Lake, and near Harrison during the March 2017 flood event, are shown compared to historical data in figures 3-5. Generally, both streamflows and concentrations during the 1996 flooding event (U.S. Geological Survey, 2018) were substantially higher than those measured in March 2017. Moreover, the 1996 samples were not width- or depth-integrated due to hazardous conditions and may underestimate actual concentrations (Beckwith, 1996). Nonetheless, total constituent concentrations (including total lead, total zinc, and total cadmium) from the March 2017 flood event were among the highest measured in the water-quality period of record. Dissolved constituent concentrations (such as dissolved cadmium and zinc), which tend to be highest during baseflow conditions, were unremarkable during the March flood event, indicating that most of the total concentrations were derived from the particulate fraction. Except for some nutrients, constituent concentrations in the Coeur d'Alene River increased from upstream (Cataldo) to downstream (Rose Lake and Harrison), with the largest increases observed between Cataldo and Rose Lake (figs. 3-5). 

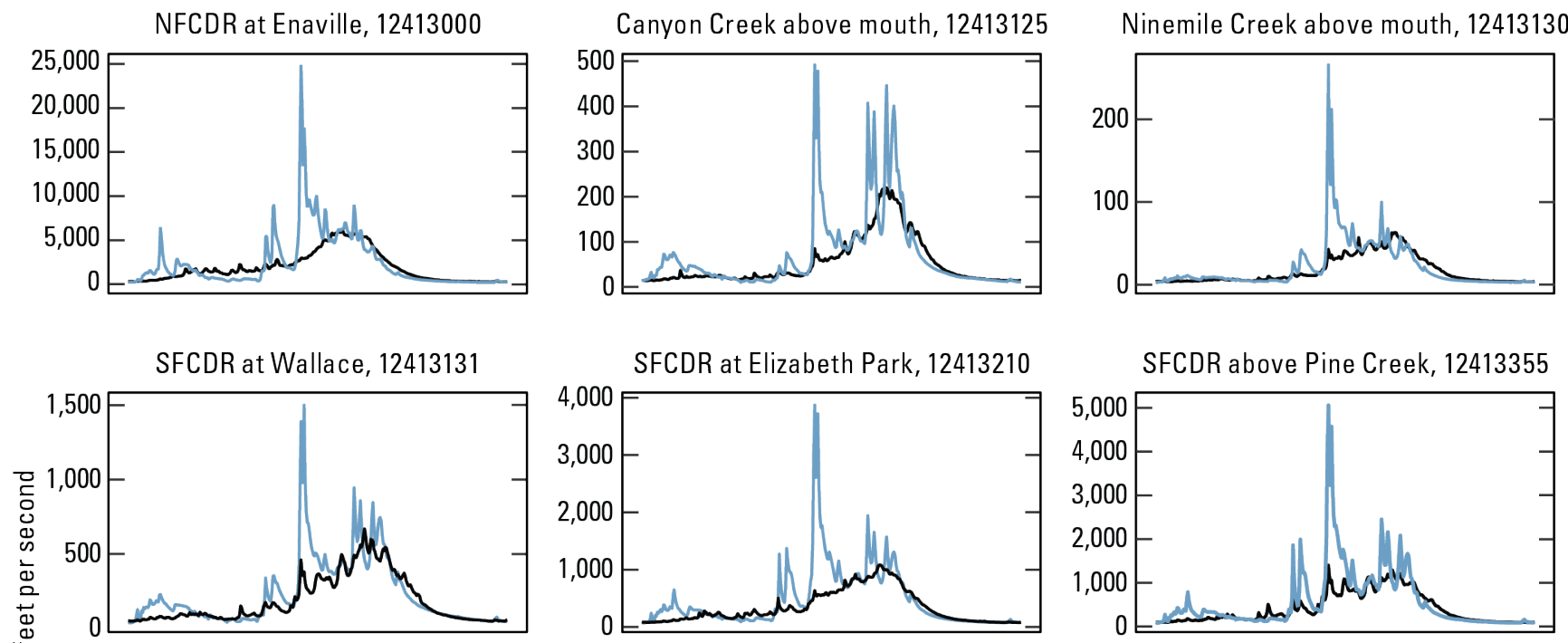

SFCDR above Pine Creek, 12413355
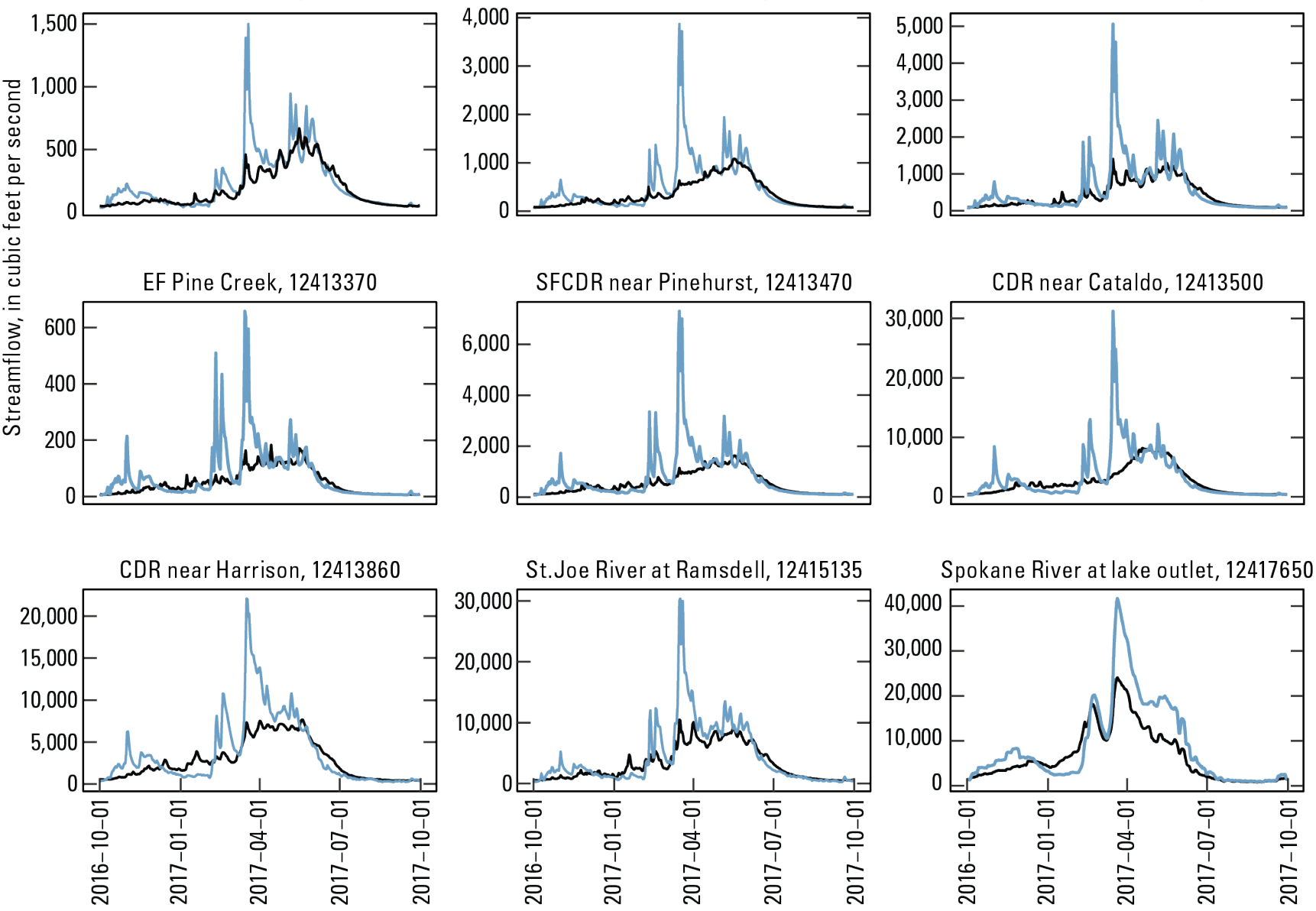

\section{EXPLANATION}

Dates

\section{Daily mean streamflow, water year 2017}

Mean daily mean streamflow for available period of record

Figure 2. Graphs showing streamflow at Basin Environmental Monitoring Program (BEMP) sites with continuous streamgages in the Coeur d'Alene River and Spokane River drainage basins, northern Idaho, water year 2017. Vertical axis scale varies by site. CDR, Coeur d'Alene River; EF, East Fork; NFCDR, North Fork Coeur d'Alene River; SFCDR, South Fork Coeur d'Alene River. 
Arsenic, dissolved, in micrograms per liter

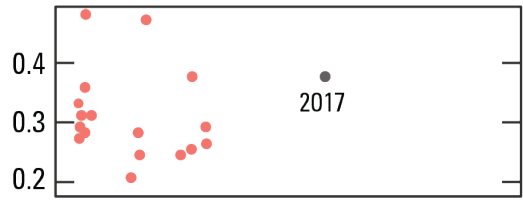

Cadmium, total, in micrograms per liter
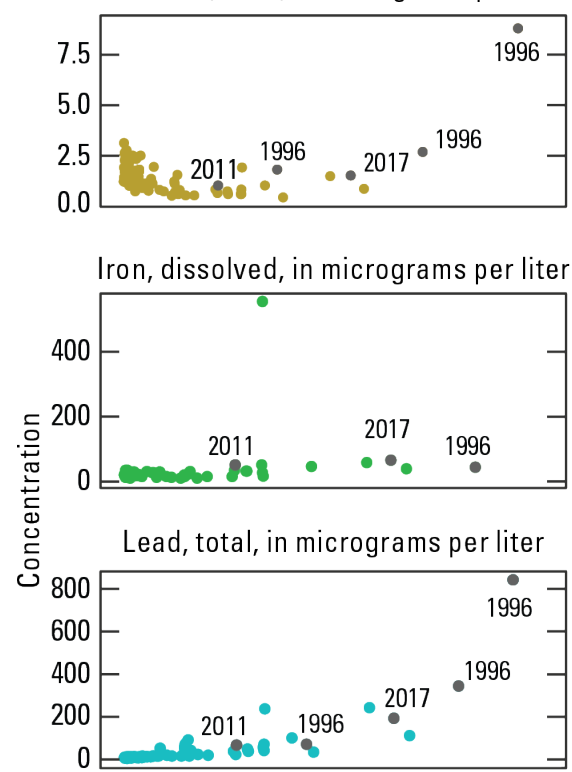

Nitrogen, total, in milligrams per liter

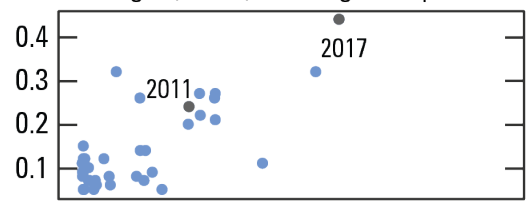

Total suspended sediment,

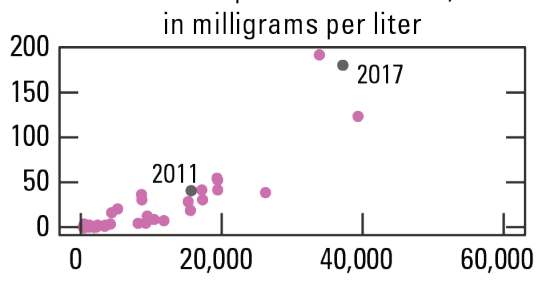

Arsenic, total, in micrograms per liter

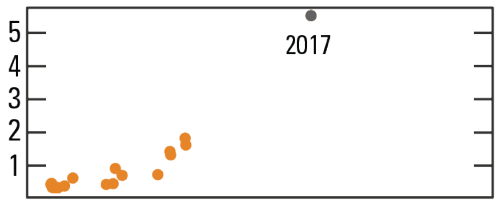

Copper, dissolved, in micrograms per liter
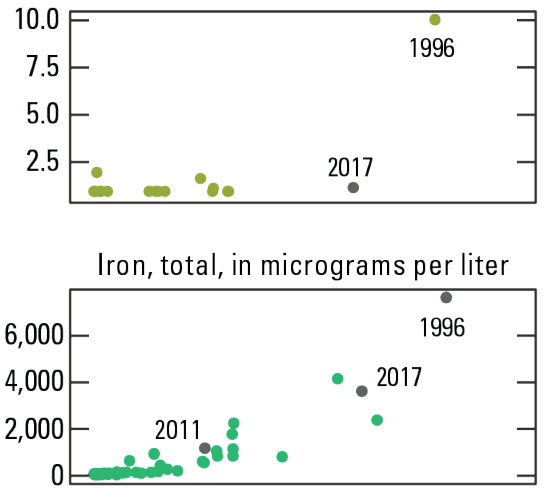

Cadmium, dissolved, in micrograms per liter

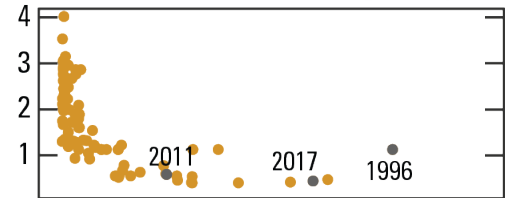

Copper, total, in micrograms per liter

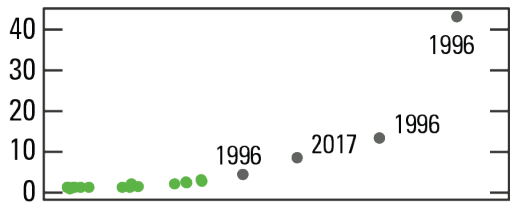

Lead, dissolved, in micrograms per liter

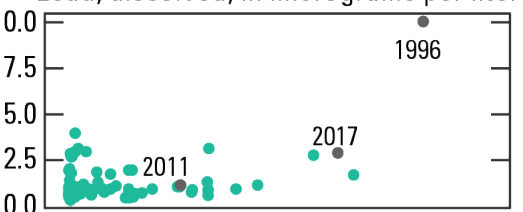

Manganese, dissolved, in micrograms per liter Manganese, total, in micrograms per liter
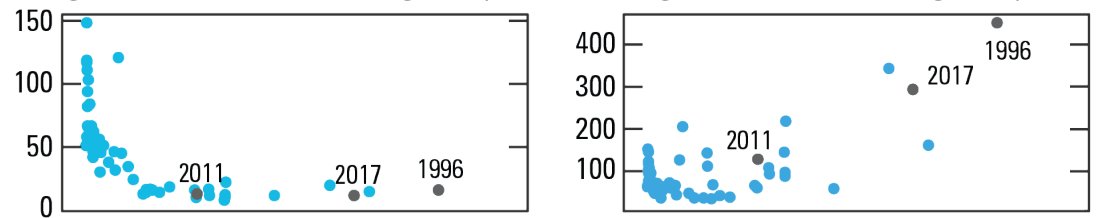

Phosphorus, ortho, in milligrams per liter

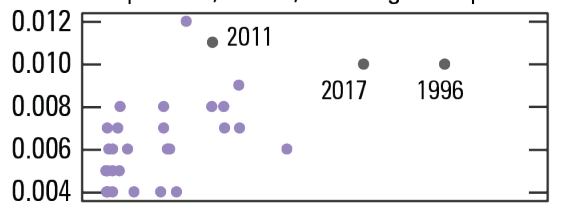

Phosphorus, total, in milligrams per liter
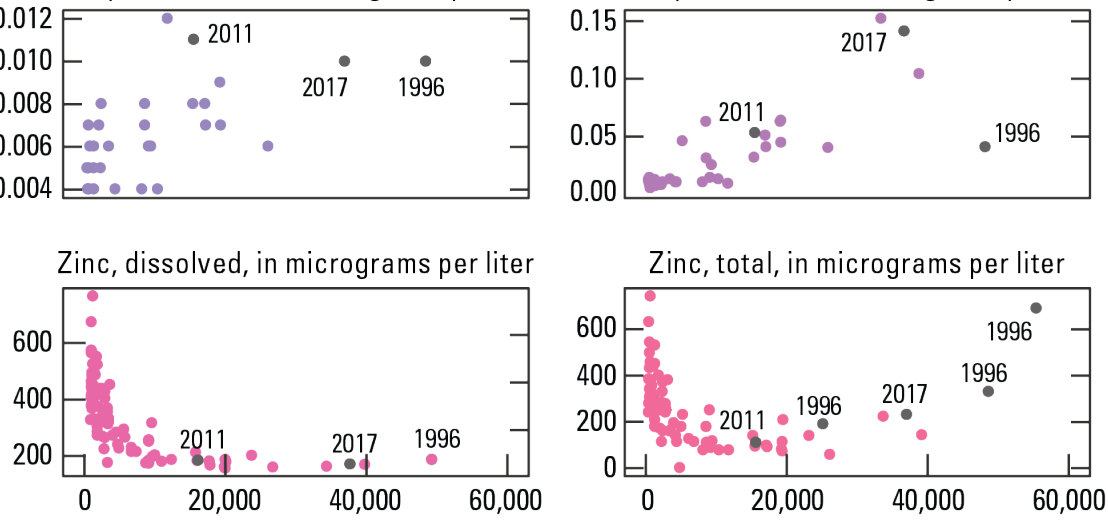

Streamflow, in cubic feet per second

Figure 3. Graphs showing constituent concentration versus streamflow in the Coeur d'Alene River near Cataldo (site 12413500), northern Idaho. Selected high-flow events are labeled by year. Data were not available for every constituent during every event. Vertical axis scale and units vary by constituent. 
Arsenic, dissolved, in micrograms per liter

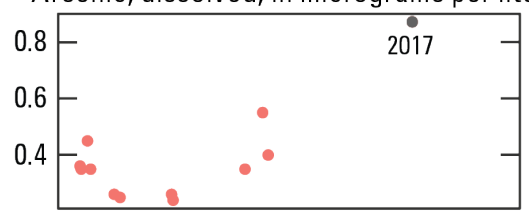

Cadmium, total, in micrograms per liter
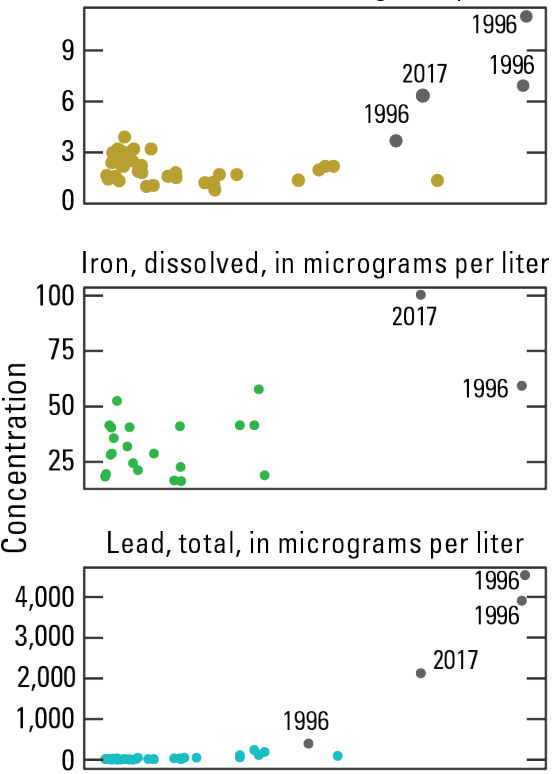

Nitrogen, total, in milligrams per liter

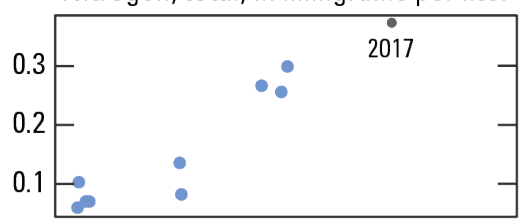

Total suspended sediment, in milligrams per liter

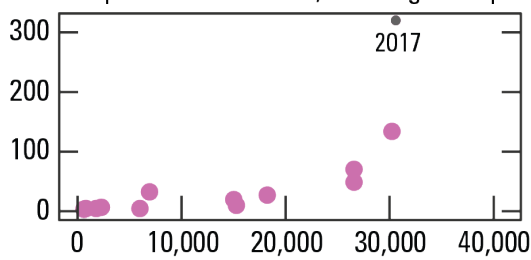

Arsenic, total, in micrograms per liter

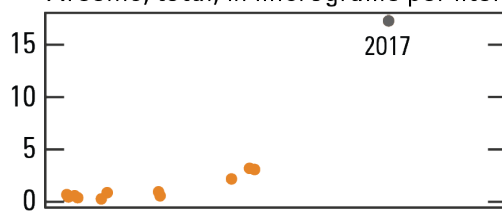

Copper, dissolved, in micrograms per liter
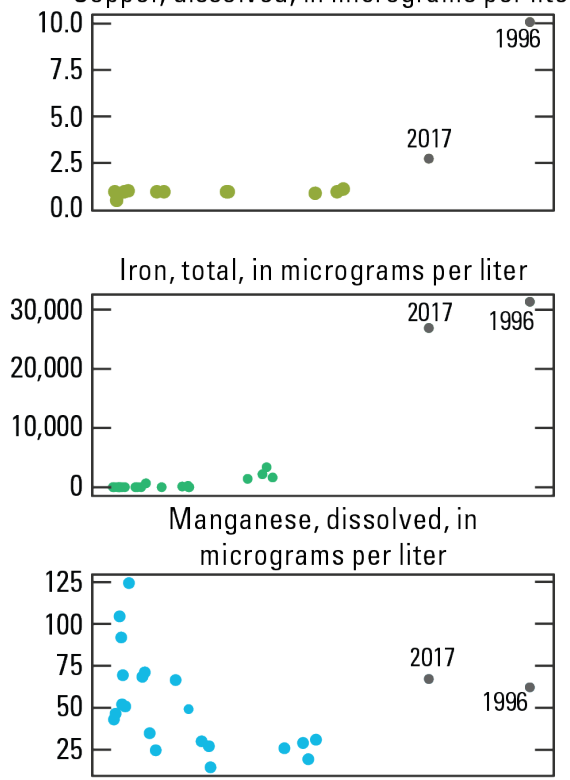

Phosphorus, ortho, in milligrams per liter

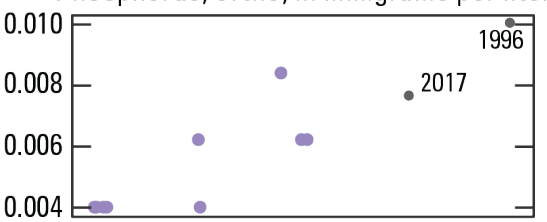

Zinc, dissolved, in micrograms per liter

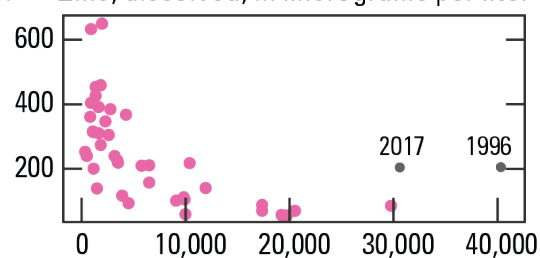

Streamflow, in cubic feet per second
Cadmium, dissolved, in micrograms per liter

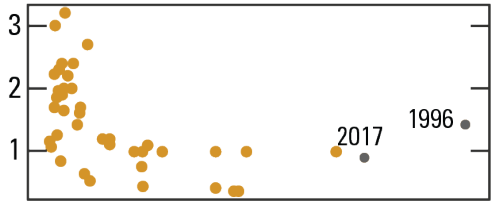

Copper, total, in micrograms per liter

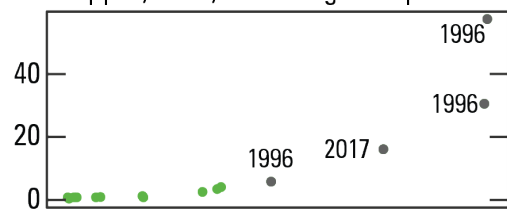

Lead, dissolved, in micrograms per liter

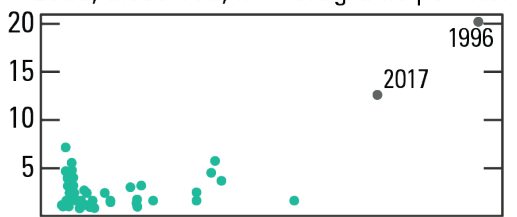

Manganese, total, in micrograms per liter

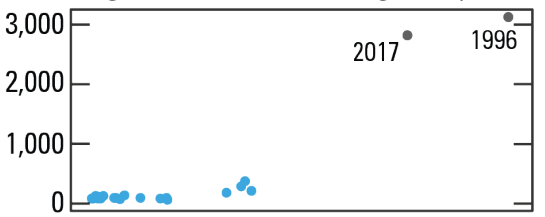

Phosphorus, total, in milligrams per liter

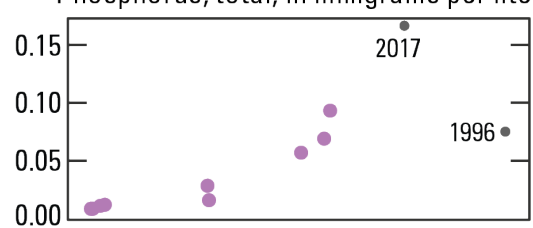

Zinc, total, in micrograms per liter

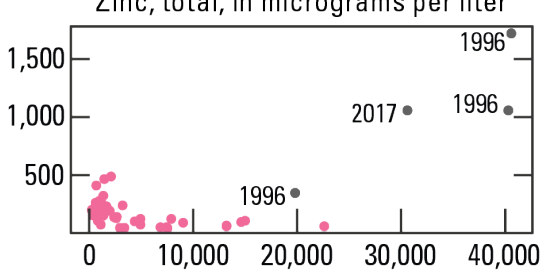

Figure 4. Graphs showing constituent concentration versus streamflow in the Coeur d'Alene River at Rose Lake (site 12413810), northern Idaho. Selected high-flow events are labeled by year. Data were not available for every constituent during every event. Vertical axis scale and units vary by constituent. 

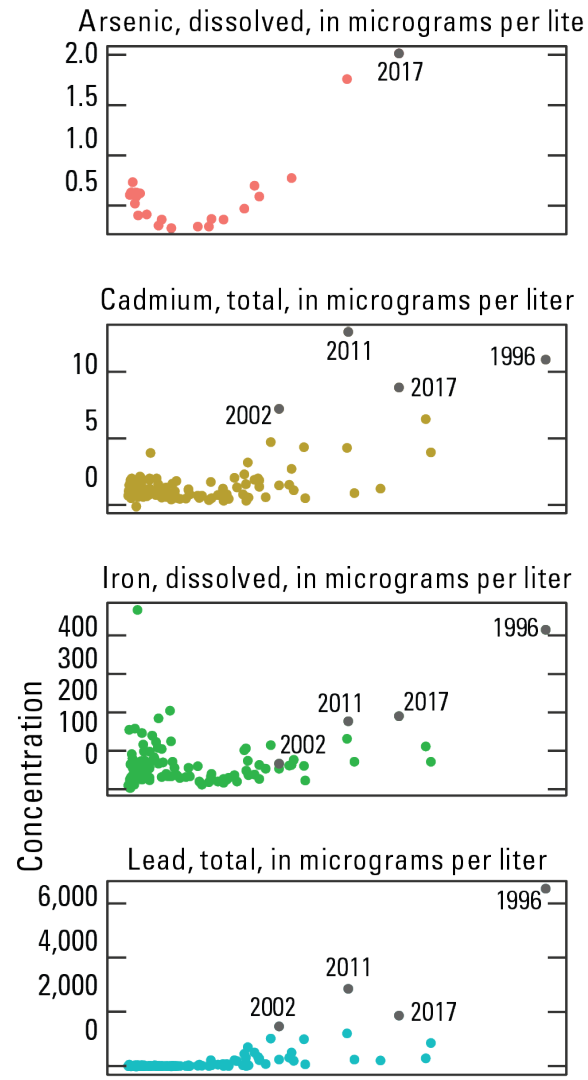

Nitrogen, total, in milligrams per liter

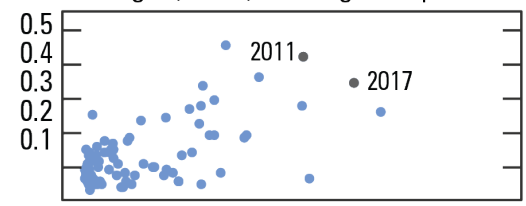

Total suspended sediment, in milligrams per liter

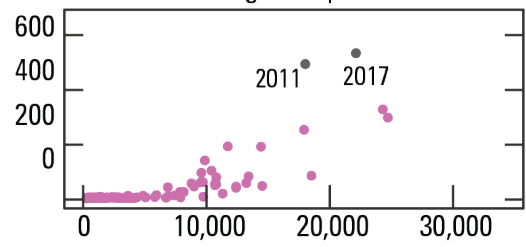

Arsenic, total, in micrograms per liter

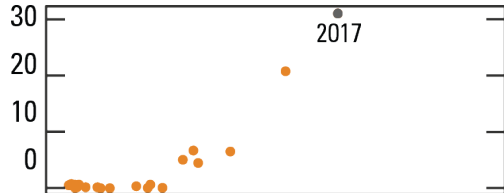

Copper, dissolved, in micrograms per liter

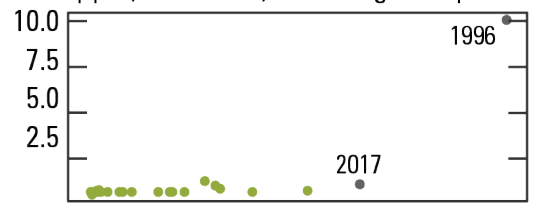

Iron, total, in micrograms per liter

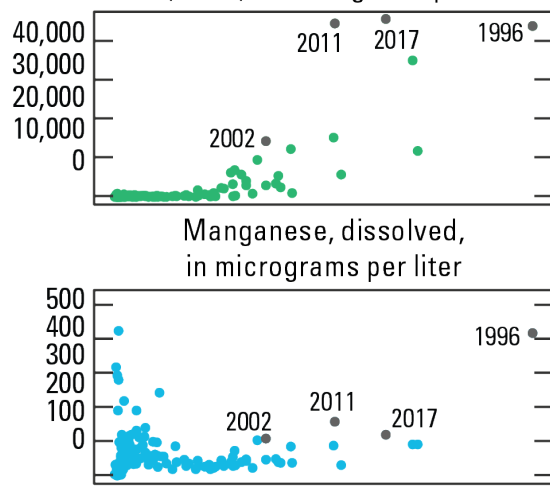

Phosphorus, ortho, in milligrams per liter

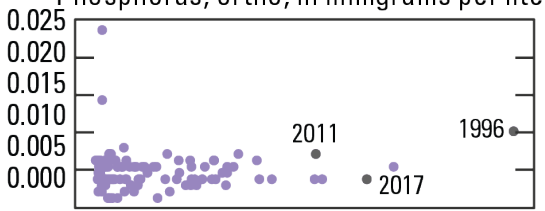

$0.000-2017$

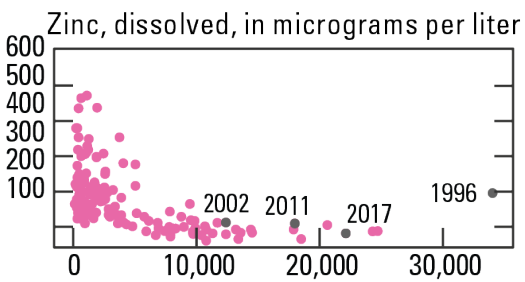

Streamflow, in cubic feet per second
Cadmium, dissolved, in micrograms per liter

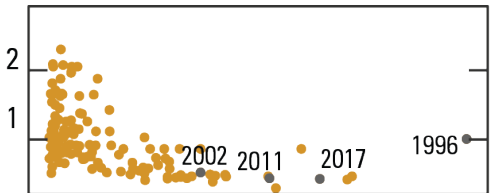

Copper, total, in micrograms per liter

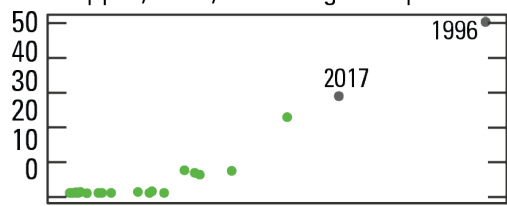

Lead, dissoloved, in micrograms per liter

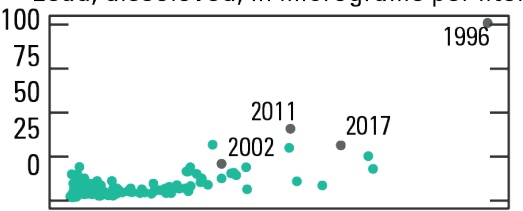

Manganese, total, in micrograms per liter

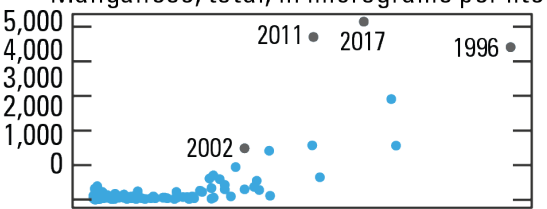

Phosphorus, total, in milligrams per liter
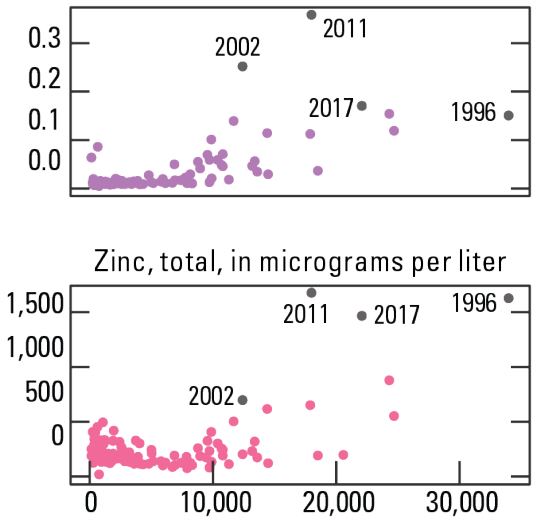

Figure 5. Graphs showing constituent concentration versus streamflow in the Coeur d'Alene River near Harrison (site 12413860), northern Idaho. Selected high-flow events are labeled by year. Data were not available for every constituent during every event. Vertical axis scale and units vary by constituent. 
Figures 6 through 8 show selected water year 2017 water-quality results (total lead, dissolved zinc and cadmium) compared to results from the previous 10 years (2007-16). Based on visual comparison, median total lead decreased in water year 2017 in Canyon Creek and in the South Fork Coeur d'Alene River near Mullan and at Wallace (fig. 6). Total lead was higher in Government Gulch and in the seeps north of tailings, and lower in Bunker Creek, but each of these sites had small 200716 sample sizes $(n=6)$ for comparison. Total lead concentrations elsewhere in the basin were similar to past measurements. Based on visual comparison, median dissolved zinc (fig. 7) and cadmium (fig. 8) decreased in Canyon Creek but increased in Ninemile Creek. This result is unexpected considering the extensive and recent remediation activities in Ninemile Creek. Median dissolved zinc and cadmium showed apparent increases in the South Fork Coeur d'Alene River at Kellogg and at Smelterville, and Government Gulch had higher dissolved zinc and cadmium concentrations, but this was likely due to repeated samples taken at these stations during baseflow conditions (when dissolved zinc and cadmium concentrations are highest) during a supplemental study conducted in September 2017. Dissolved zinc and cadmium were lower in water year 2017 in the Coeur d'Alene River near Harrison, in the Spokane River at the lake outlet, and in the seeps north of tailings (figs. 6 and 7). Continued data collection at these stations will help to determine whether these decreases were related to high streamflows in water year 2017 or if they represent a more persistent change.

\section{Quality-Control Samples}

Nine replicate samples and ten field blanks were collected in water year 2017. Generally, analytical results were in good agreement (relative percent difference [RPD] less than 20 percent) between parent and replicate samples. However, higher RPDs (up to a maximum of 115 percent) were observed between copper, cadmium, and lead results in several filtered samples that had low concentrations of these constituents. In the blank samples, most constituents were not detected. However, filtered copper and unfiltered and filtered lead were detected in most blank samples, albeit at low concentrations near the reporting limit. Given the occurrence of copper and lead in blanks, and the high RPDs in copper and lead results in replicates, the USGS will carefully evaluate equipment cleaning and sample processing procedures in water year 2018. This evaluation will include collecting sequential equipment blanks (blanks taken after each processing step) to identify problematic equipment and (or) procedures. 

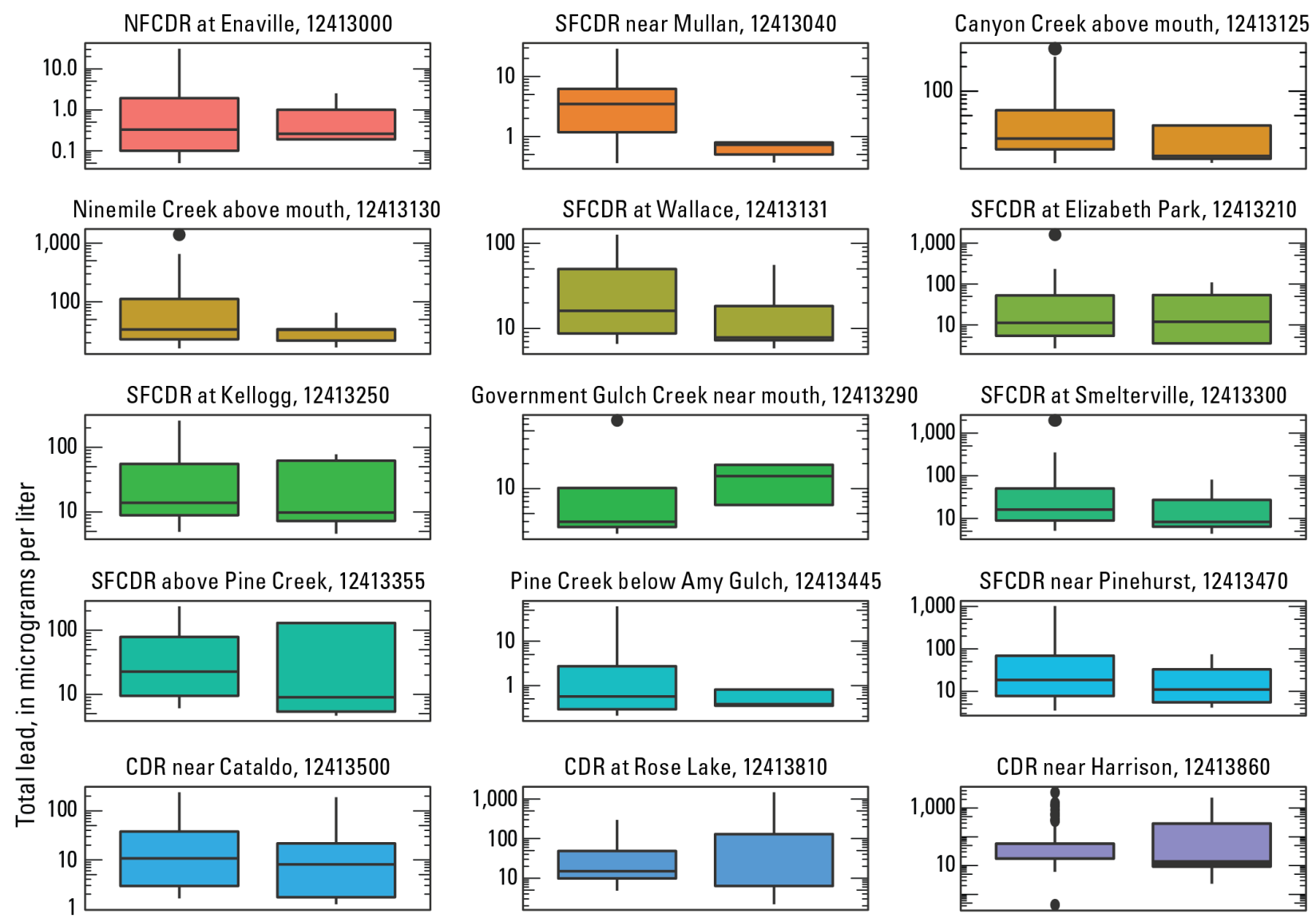

Government Gulch Creek near mouth, 12413290
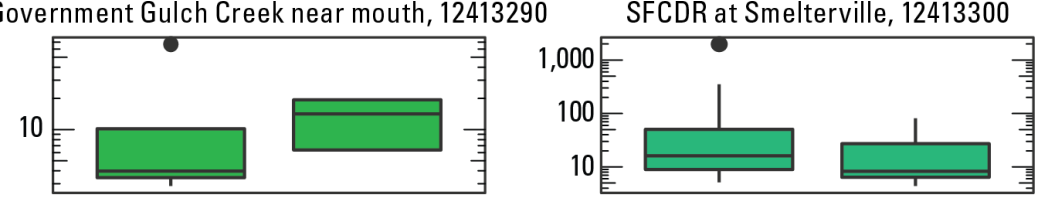

Pine Creek below Amy Gulch, 12413445
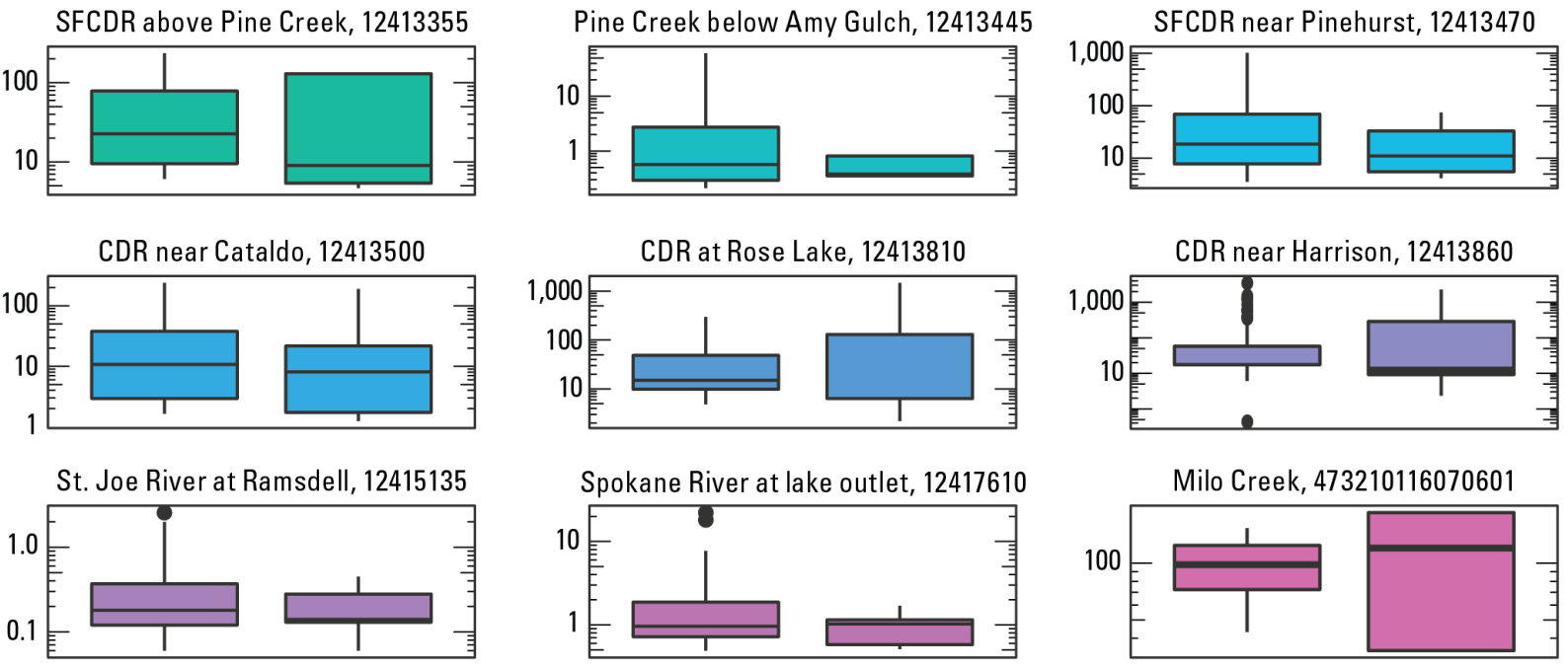

Bunker Creek at mouth, 473252116095301

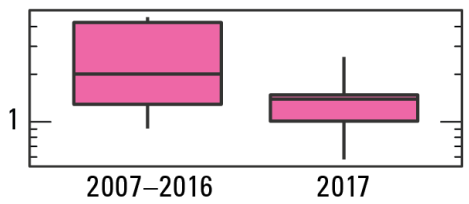

Seeps north of tailings, 473254116091200
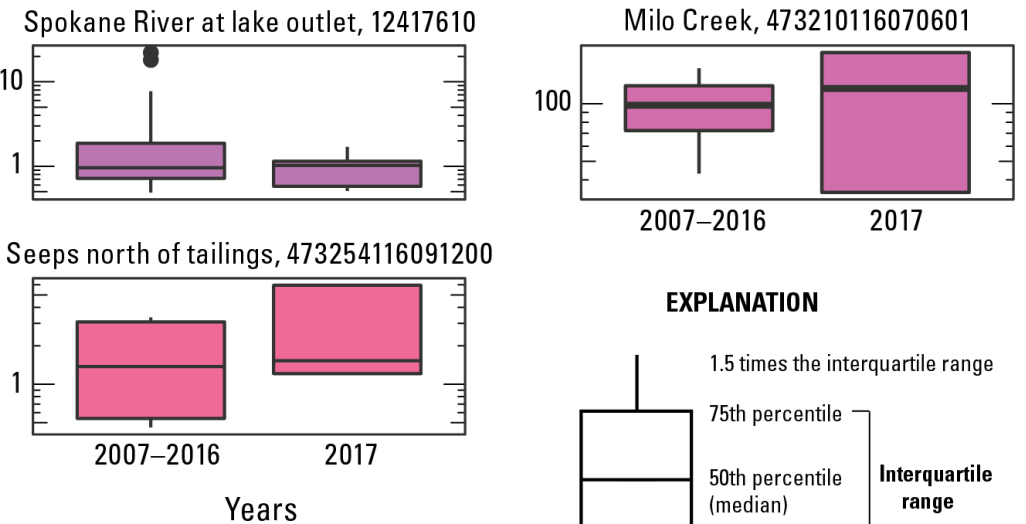

EXPLANATION

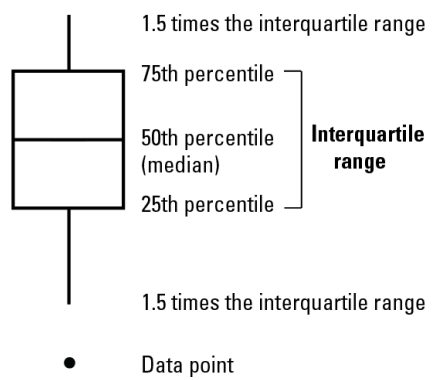

Figure 6. Boxplots showing total lead concentrations at Basin Environmental Monitoring Program (BEMP) sites in water year 2017 versus $2007-16$. Vertical axis scale is logarithmic and varies by site. Sample size varies by site: 2007-16, $n=6-62 ; 2017, n=3-8 . C D R$, Coeur d'Alene River; NFCDR, North Fork Coeur d'Alene River; SFCDR, South Fork Coeur d'Alene River. 

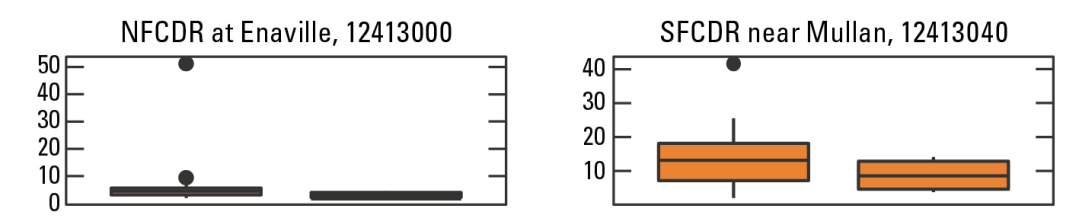

Canyon Creek above mouth, 12413125
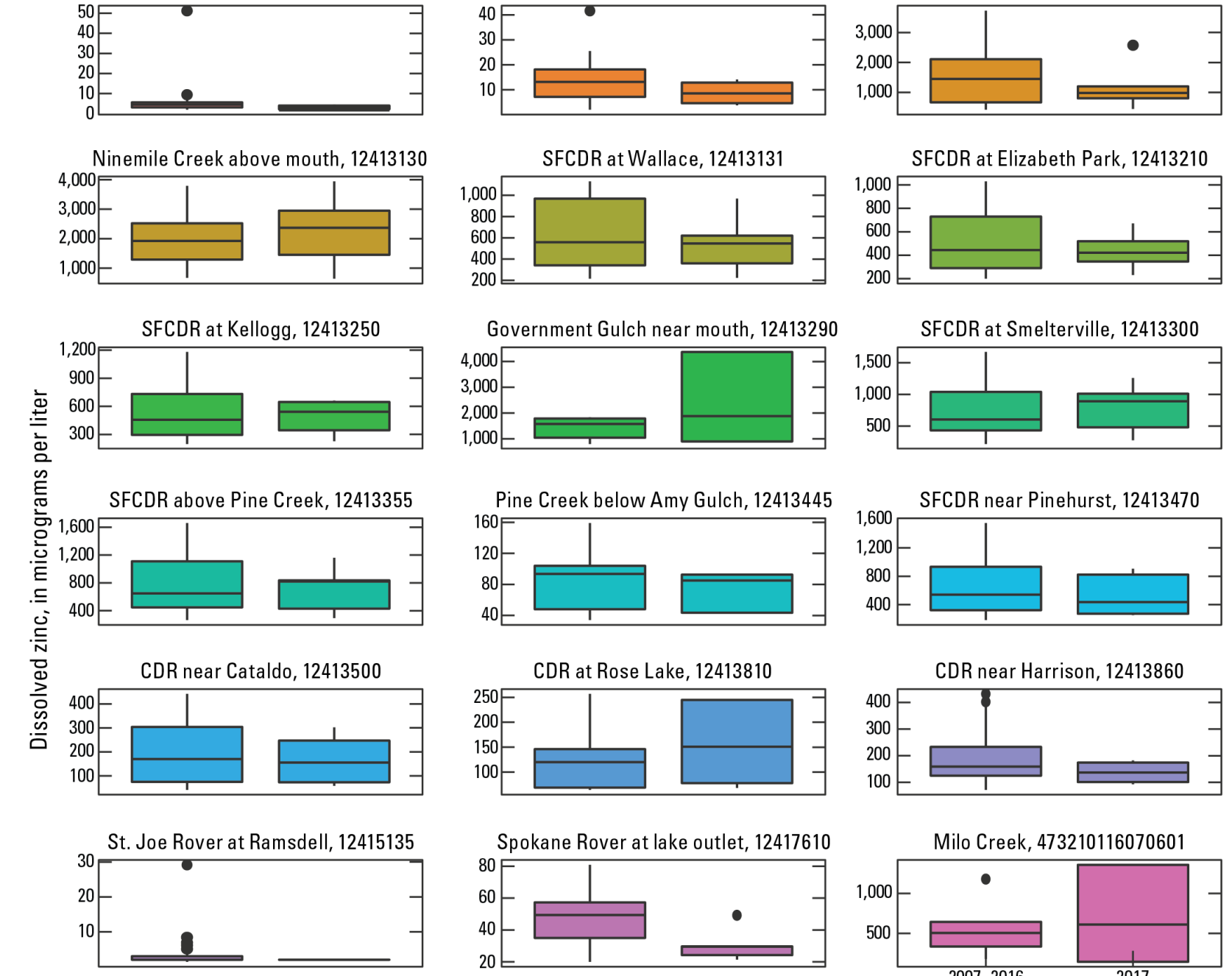

Spokane Rover at lake outlet, 12417610
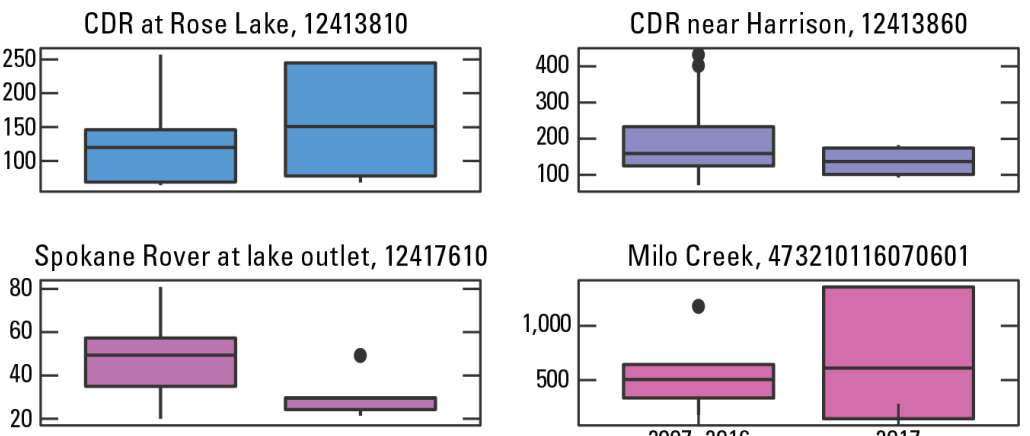

Bunker Creek at mouth, 473252116095301
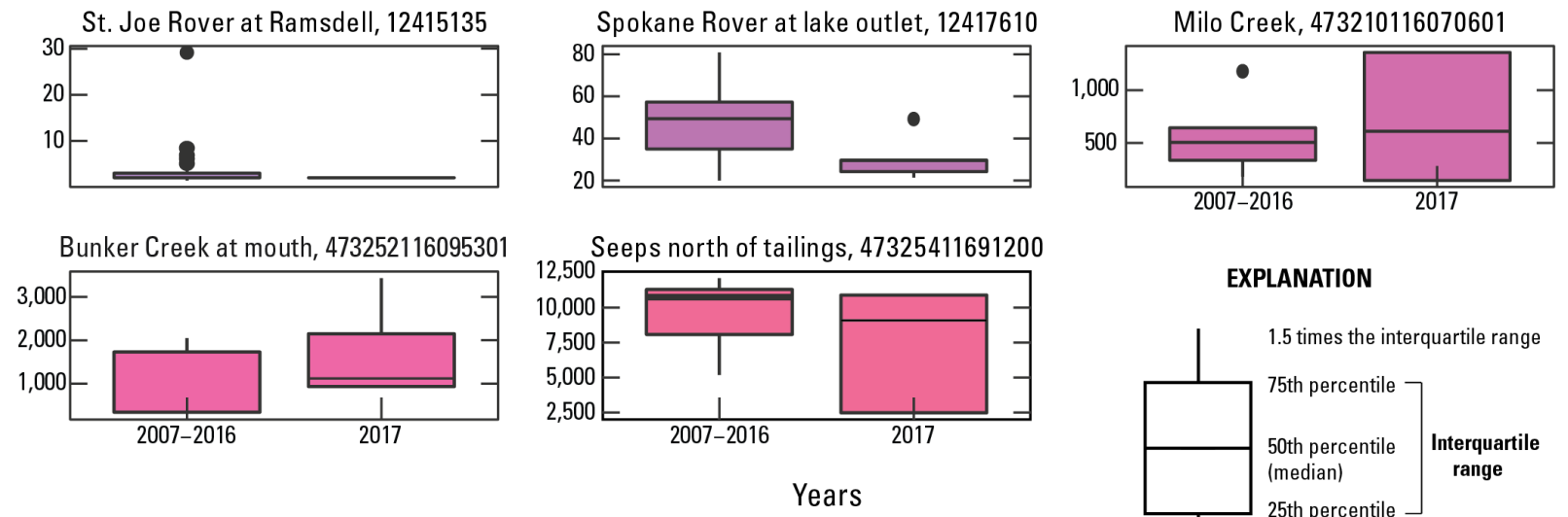

EXPLANATION

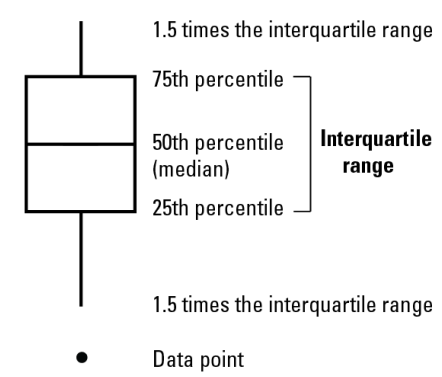

Figure 7. Boxplots showing dissolved zinc concentrations at Basin Environmental Monitoring Program (BEMP) sites in water year 2017 versus 2007-16. Vertical axis scale varies by site. Sample size varies by site: 2007-16, $n=6-62 ; 2017, n=3-8$. CDR, Coeur d'Alene River; NFCDR, North Fork Coeur d'Alene River; SFCDR, South Fork Coeur d'Alene River. 

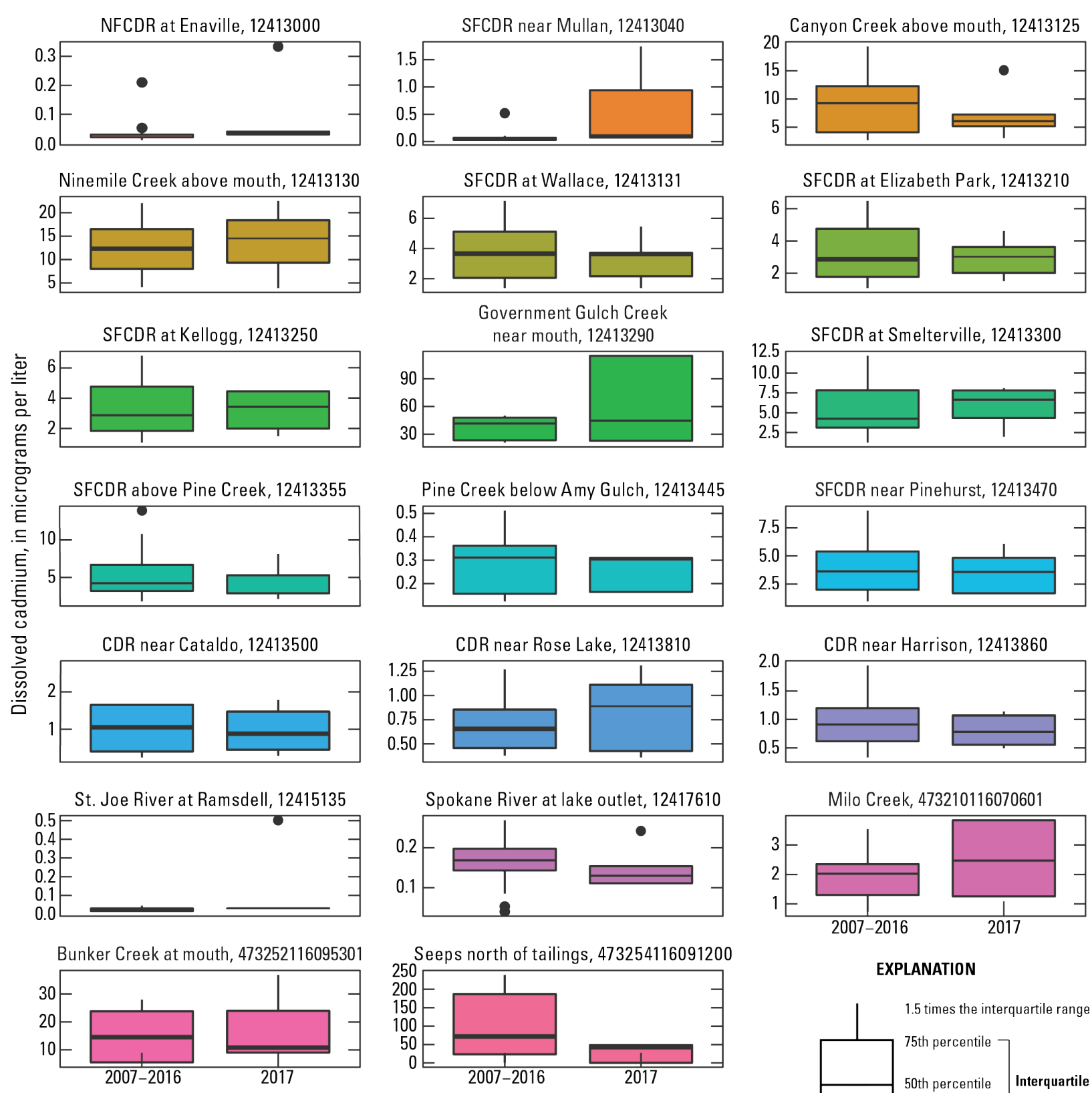

EXPLANATION

Years

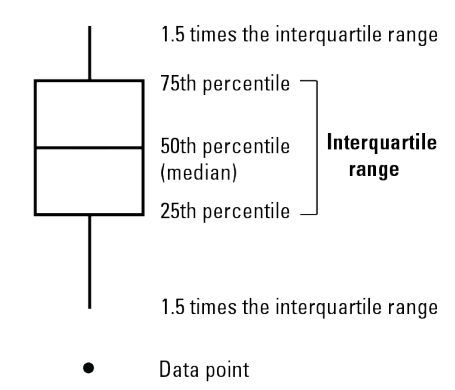

Figure 8. Boxplots showing dissolved cadmium concentrations at Basin Environmental Monitoring Program (BEMP) sites in water year 2017 versus 2007-16. Vertical axis scale varies by site. Sample size varies by site: 2007-16, $n=6-62 ; 2017, n=3-8$. CDR, Coeur d'Alene River; NFCDR, North Fork Coeur d'Alene River; SFCDR, South Fork Coeur d'Alene River. 


\section{References Cited}

Beckwith, M.A., 1996, Water-quality data collected during floods in the Coeur d'Alene River, northern Idaho, February 1996: U.S. Geological Survey Fact Sheet 219-96, 4 p. [Also available at http://pubs.er.usgs.gov/publication/fs21996.]

Clark, G.M., and Mebane, C.A., 2014, Sources, transport, and trends for selected trace metals and nutrients in the Coeur d'Alene and Spokane River Basins, Idaho, 1990-2013: U.S. Geological Survey 2014-5204, 74 p. [Also available at http://pubs.er.usgs.gov/publication/sir20145204.]

Clark, G.M., and Perreault, L.M., 2017, Quality Assurance Project Plan (QAPP) for U.S. Geological Survey surface water sampling under the Coeur d'Alene Basin Environmental Monitoring Program at the Bunker Hill superfund site-OU2 and OU3: U.S. Environmental Protection Agency, Region 10, 51 p.

Levesque, V.A., and Oberg, K.A., 2012, Computing discharge using the index velocity method: U.S. Geological Survey Techniques and Methods 3-A23, p. 148. [Also available at https://pubs.usgs.gov/tm/3a23/.]

Mueller, D.K., Schertz, T.L., Martin, J.D., and Sandstrom, M.W., 2015, Design, analysis, and interpretation of field quality-control data for water-sampling projects: Reston, Virginia, 4-C4, 65 p. [Also available at http://pubs.er.usgs.gov/publication/tm4C4.]

Mueller, D.S., Wagner, C.R., Rehmel, M.S., Oberg, K.A., and Rainville, F., 2013, Measuring discharge with acoustic Doppler current profilers from a moving boat: Reston, VA, 3-A22. 116 p. [Also available at http://pubs.er.usgs.gov/publication/tm3A22.]

Rantz, S.E., 1982, Measurement and computation of streamflow-Volume 1, measurement of stage and discharge: U.S. Geological Survey 2175, 284 p. [Also available at http://pubs.er.usgs.gov/publication/wsp2175_vol1.]

Turnipseed, D.P., and Sauer, V.B., 2010, Discharge measurements at gaging stations: U.S. Geological Survey 3-A8, chap. A8, 87 p. [Also available at http://pubs.er.usgs.gov/publication/tm3A8.]

U.S. Environmental Protection Agency, 2002, The Bunker Hill Mining and Metallurgical Complex Operable Unit 3, record of decision: U.S. Environmental Protection Agency, 527 p. [Also available at https://nepis.epa.gov.]

U.S. Environmental Protection Agency, 2012, Interim Record of Decision (ROD) amendment, Upper Basin of the Coeur d'Alene River, Bunker Hill Mining and Metallurgical Complex superfund site: U.S. Environmental Protection Agency, 488 p. [Also available at https://semspub.epa.gov/work/10/664107.pdf.]

U.S. Geological Survey, 2018, National Water Information System (NWIS): U.S. Geological Survey, https://waterdata.usgs.gov/id/nwis/current/?type=BEMP.

U.S. Geological Survey, variously dated, National field manual for the collection of waterquality data: U.S. Geological Survey Techniques of Water-Resources Investigations, book 9, chaps. A1-A10, at http://pubs.water.usgs.gov/twri9A. 

Publishing support provided by the U.S. Geological Survey Science Publishing Network, Tacoma Publishing Service Center

For more information concerning the research in this report, contact the Director, Idaho Water Science Center

U.S. Geological Survey

230 Collins Road

Boise, Idaho 83702

http://id.water.usgs.gov 
Nㅗㅀ

d)

$\stackrel{\square}{\leftrightarrows}$

$\frac{2}{\frac{1}{D}}$

एँ

$\Xi$

罗.

․․․

帚

蛋

3

을.

뭉

$\stackrel{8}{\circ}$

3

핳

$\exists$

응

गे

อิ

ఫ

丞

2

ก

I

$\stackrel{9}{3}$

끄

ग

응

స్ㅇํㅇ

立 